\title{
Sistemas de recuperación de información en bancos de imágenes comerciales. Eficacia de la búsqueda inversa de imágenes
}

\author{
JaVier Trabadela-Robles \\ Universidad de Extremadura \\ jtrarob@unex.es \\ https://orcid.org/0000-0001-5338-9257
}

\author{
Samanta Flores-Jaramillo \\ Centro de Estudios Extremeños, Diputación de Badajoz \\ sflores@dip-badajoz.es \\ https://orcid.org/0000-0002-9401-5718
}

\section{Image retrieval systems in commercial stock photography websites. Reverse image searches effectiveness}

\begin{abstract}
RESUMEN
El objetivo principal de este estudio es analizar la eficacia en la recuperación de imágenes en los bancos de imágenes comerciales en internet al realizarse una búsqueda inversa (de una imagen mediante otra previa). Para ello se analizan los sistemas de recuperación de imágenes que incluyen, se selecciona un conjunto de imágenes sencillas de los géneros fotográficos paisaje, bodegón y retrato y se procede a su búsqueda en una selección de bancos de imágenes. Los resultados se comparan con las imágenes de referencia atendiendo a los atributos de textura, forma y colores predominantes. Por último, también se realiza una búsqueda textual complementaria a efectos comparativos. Se concluye de los resultados y su análisis que la búsqueda inversa solo es ofrecida por los bancos comerciales de pago, que funciona mejor en imágenes de unos géneros que de otros y que, en general, la búsqueda mediante imágenes de ejemplo puede ser útil y efectiva para una primera consulta no semántica.
\end{abstract}

PALABRAS CLAVE

Sistemas de recuperación de imágenes; SRI; CBIR; Atributos visuales; Fotografía de stock; Microstock.

\section{ABSTRACT}

The aim of this study is to analyze the effectiveness of image retrieval in stock photography websites when a reverse search (an image query by a previous one) is performed. For this purpose, stock photography sites image retrieval systems are analysed; a set of simple images from the photographic genres (landscape, still life and portrait) is selected and a search of them in a sample of sites is processed. The results are compared with the reference images according to the attributes of texture, shape and predominant colours. Finally, a complementary textual search is also carried out for comparative purposes. It is concluded from the results and their analysis that reverse search is only offered by fee-based stock fotography sites, that it works better on images of some genres than others and that, in general, searches using sample images can be useful and effective for a first non-semantic query.

\section{KEYWORDS}

Image retrieval systems; CBIR; Visual attributes; Stock photography; Microstock. 


\section{Introducción}

En la sociedad actual prima lo visual sobre otros tipos de contenidos como los textuales, de modo que se generan millones de imágenes al día. A pesar de ello, existe una ingente demanda de imágenes para su incorporación a todo tipo de publicaciones. Además, debido a la creciente concienciación de instituciones, empresas y particulares sobre el adecuado uso de las imágenes en relación con la propiedad intelectual, la mayoría de los usuarios recurre (o debería recurrir) a fuentes legales de imágenes como los bancos de imágenes en internet.

En las últimas dos décadas los bancos de imágenes, especialmente los comerciales, han crecido en número, especialmente los denominados de microstock (Codina, 2010; Defillippi et al., 2014; Voronov e Ivanov, 2016), que son los que ofrecen imágenes a muy bajo coste $y$, a diferencia del sector de macrostock, el de microstock apenas ofrece fotografía editorial entre sus fondos, centrándose en la fotografía creativa. También es destacable que han aumentado los bancos que ofrecen imágenes de forma gratuita, cuyo modelo de negocio se basa en la atribución, en la publicidad directa en su sitio web y en el emplazamiento patrocinado entre sus fondos de imágenes de bancos comerciales de pago.

Debido a esta competencia feroz, los bancos de imágenes comerciales se ven en la necesidad de ofrecer mejoras continuas de diseño y funcionalidad y, también, de optimizar la eficacia del sistema para el usuario final, de modo que así se posicionan y diferencian de sus competidores.

En este contexto, como se expone en el marco teórico, se hace necesario un análisis actualizado de los sistemas de recuperación que ofrecen los bancos de imágenes en internet y, en concreto, analizar cuáles ofrecen la posibilidad de la búsqueda inversa de imágenes y si ésta es eficaz y en qué grado.

\subsection{Objetivos}

En el contexto presente descrito de producción y consumo masivo de imágenes, de necesidad de su uso correcto y de una amplia oferta de bancos de imágenes, el objetivo principal de este trabajo es conocer la eficacia en la recuperación de imágenes tras realizar una búsqueda de imágenes a través de una dada a nivel de usuario no especializado.
Un objetivo específico, imprescindible para lograr el objetivo principal, es estudiar los sistemas de recuperación de imágenes que ofrecen los bancos de imágenes comerciales en internet.

Se pretende averiguar si existe alguna diferencia en la eficacia de la búsqueda inversa en función de la tipología de los bancos de imágenes.

También se persigue realizar una búsqueda textual de los términos que describen las imágenes elegidas para examinar qué resultados ofrecen los bancos (y así poder compararlos).

Por último, realizar un análisis comparativo temporal de la eficacia de la recuperación tras la búsqueda inversa. Para ello se testea el funcionamiento de los bancos seleccionados en dos oleadas en periodos separados por algo menos de un año. De este modo se pretende dilucidar si los bancos han implementado alguna mejora en el sistema de recuperación durante ese tiempo.

\subsection{Preguntas de investigación}

En relación con los objetivos planteados, surgen las siguientes preguntas de investigación respecto a los bancos de imágenes (comerciales) y sus sistemas de recuperación de imágenes:

¿Disponen los bancos de imágenes de sistemas de recuperación basados en imágenes previas? ¿Hay diferencias entre los bancos en función de si son comerciales o gratuitos? ¿Son realmente eficaces estos sistemas de recuperación de búsqueda inversa? ¿Serán más eficaces en imágenes de un género fotográfico que de otro? ¿Seguirán siendo eficaces las búsquedas textuales describiendo las imágenes comparadas con la visual? Y, por último, ¿las mejoras que se hayan podido introducir en los bancos de imágenes entre las dos oleadas de análisis aumentarán la eficacia en la recuperación?

Estas cuestiones surgen de las hipótesis de que, tal y como sugieren los numerosos y continuos estudios sobre los lenguajes computacionales y algoritmos para la comparación de imágenes (Sarwar et al., 2019; Gu et al., 2020; Tong et al., 2020), estos sistemas se encuentran en una fase de mejora continua, de modo que funcionan de una forma adecuada con imágenes que no incluyan muchos elementos, lo que Lin et al. (2014) denominan "imágenes icónicas objeto" e "imágenes icónicas escena". En este sentido, las expectativas de cambio en los resultados de una oleada a otra no son muy grandes, ya que las mejoras suelen ser lentas (no obstante, se ha querido hacer la comparación para 
constatar esa hipótesis de partida, aunque sea en un periodo de tiempo apenas interanual).

En relación con los SRI, se prevé que, de forma general, los bancos comerciales y aquellos de extensa trayectoria y mayores recursos (Codina y Palma, 2001; Codina, 2011) dispongan de más sistemas de recuperación de imágenes que los gratuitos (Codina y Lopezosa, 2020), dada su menor capacidad de inversión.

También se espera que las búsquedas textuales de imágenes mediante los términos precisos que las describen no sean muy eficaces.

\section{Marco teórico}

Desde que en la última década del siglo XX las agencias fotográficas se fueran transformando (Figueroa et al., 1994; López Yepes y Sánchez Gay, 1994) en lo que hoy se conoce como bancos de imágenes, la comunidad científica los ha analizado desde diversas perspectivas, entre otras, la propia definición de los mismos (Codina y Palma, 2001), su tipología y características principales (López Yepes, 2002, Codina, 2011; Trabadela, 2018), estudios de casos (Doucet, 2008; Saorín y Pastor, 2011; Taute, 2013; Lucía, 2015; Trabadela, 2017), el uso de sus fondos en disciplinas como la Publicidad (Marcos et al., 2011) o su relación con la conservación y difusión del patrimonio
(Cuenca, 2001), por citar algunas de las investigaciones sobre el objeto de estudio.

Los bancos de imágenes en internet son bases de datos cuyos documentos son imágenes. Por tanto, requieren de un sistema interno de gestión semejante al de otros tipos de bases de datos. Como se ha mencionado, los lenguajes internos computacionales, lo que Martínez (2013) denomina "algoritmos de similaridad", están en constante evolución y mejora para que las consultas a los fondos sean lo más eficaces posibles.

Aunque en este trabajo no se ponga el foco en la gestión interna del banco, sino en la efectividad real de la búsqueda para el usuario final no experto, sí resulta pertinente referirse a algunos de los elementos esenciales de funcionamiento interno de los bancos de imágenes que, además, implican determinadas funcionalidades visibles y usables para el destinatario final. Tal es el caso de los sistemas de recuperación de imágenes (SRI).

Los SRI han sido ampliamente estudiados desde el punto de vista documental (entre otros trabajos de interés: Muñoz, 2001; Robledano, 2002; Pérez, 2006; Perdices y Perianes, 2011; Ménard y Smithglass, 2012; Perdices y Perianes, 2014). En la literatura previa estos y otros autores definen y describen los distintos sistemas y establecen los problemas habituales. El SRI textual que ofrece la mayoría de los bancos de imágenes se fundamenta, desde el punto de vista documental, en la

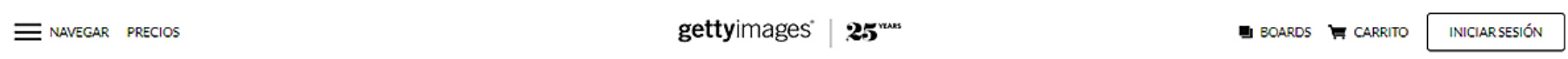

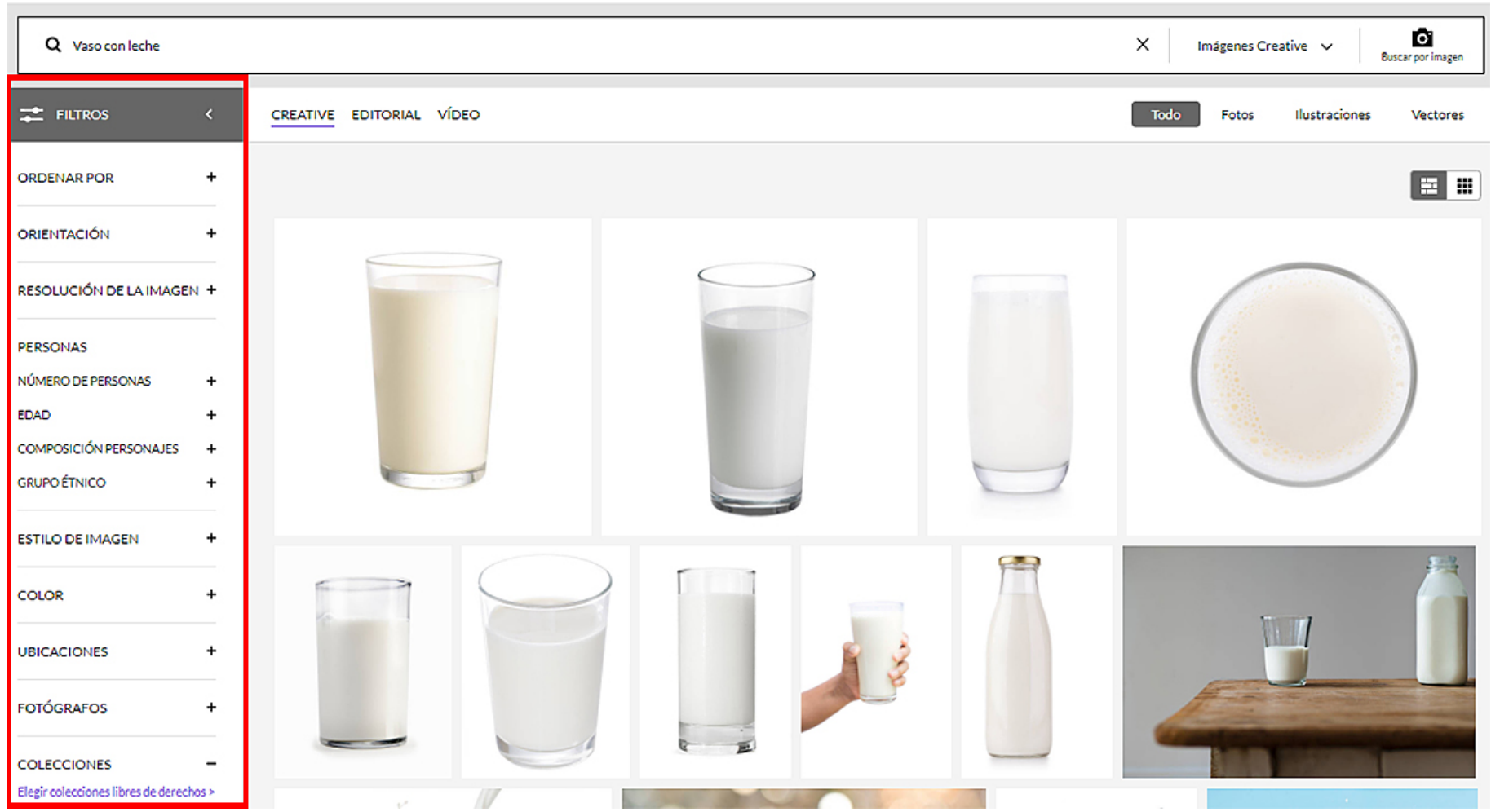

Figura 1. Ejemplos de la búsqueda por facetas/ filtros en Getty Images. Fuente: Sitio web de Getty Images. 


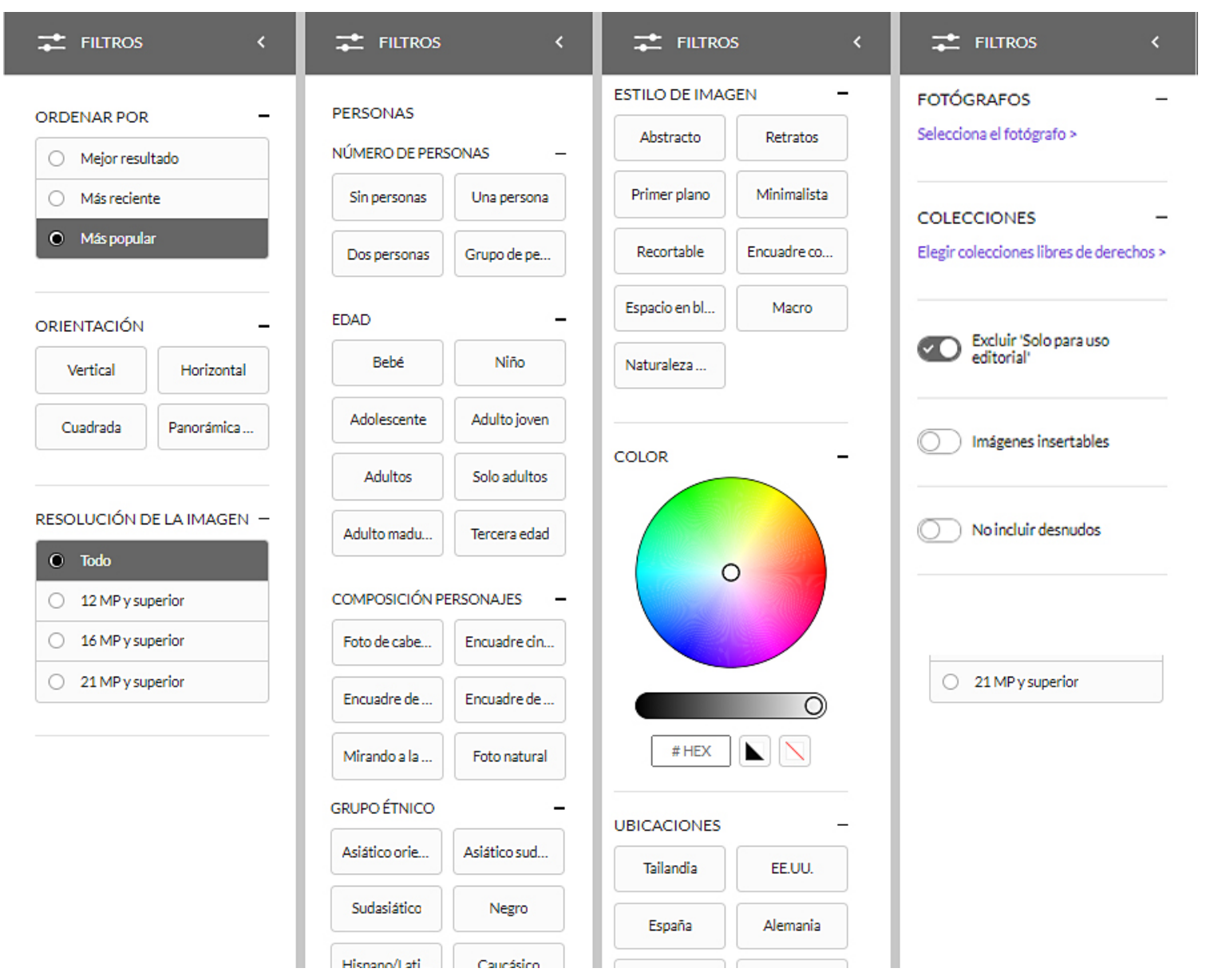

Figura 2. Despliegue de las opciones de facetas/ filtros en Getty Images. Fuente: Elaboración propia a partir del sitio web de Getty.

necesidad de utilizar descriptores (de un tesauro), que luego se correspondan con las palabras clave que utilice el usuario final en la consulta. Su principal inconveniente es el carácter polisémico de las imágenes, relacionado con el uso de dos lenguajes distintos, el icónico y el textual, tanto por parte del usuario que realiza la consulta, como del documentalista que agregó los descriptores de las imágenes presentes en los fondos.

Lo SRI también permiten consultas basadas en características de la imagen. El usuario, mediante una serie de filtros o facetas, en el momento de la consulta le indica al sistema las características visuales representativas de la imagen que busca, el cual representa regiones con formas, colores, y texturas (Figuras 1 y 2). El sistema cuenta con descriptores visuales de imágenes representativas de los conceptos que soporta en las consultas. El resultado se basa en la similitud entre los descriptores visuales de los conceptos y los de las imágenes del repositorio. También el sistema puede incorporar imágenes que realicen la función de filtro, la búsqueda en este caso se realiza mediante la consulta textual del usuario y la seleccionada en la imagen de muestras. Esta sería la búsqueda mediante facetas o filtros y es un SRI basado en contenido (CBIR). Mediante estos sistemas se analiza los contenidos reales de las imágenes, es decir, consideran los colores, formas, texturas o cualquier otra información derivada de las mismas (Figura 2), pero dejan a un lado el contenido semántico (que sigue siendo en la actualizad el principal reto a resolver).

Las técnicas de comparación utilizada en la mayoría de estos sistemas se realizan (Pérez, 2006): para el color, la búsqueda relacionada con esta propiedad implica comparar el histograma de color de la imagen de ejemplo con los de las imágenes del fondo; en relación a la textura, el sistema tiene en cuenta los patrones visuales y como se distribuyen espacialmente; por último, para comparar las formas, el sistema considera la forma de una parte en concreto, de modo que las formas se detectan mediante segmentación o por detección de aristas.

Por último, la búsqueda inversa o búsqueda de una imagen mediante otra previa es un SRI que están incorporando los bancos desde hace unos pocos años (Figura 3). También se utilizan en los motores de búsqueda como Google (Adrakatti et al., 2016). Su funcionamiento consiste en el análisis automático de la imagen de ejemplo, su transformación en un modelo matemático de algoritmos que son comparados con los de esa misma tipología de las imágenes de los fondos de los bancos 
de imágenes, mostrándose las que sean similares. Este sistema de búsqueda inversa puede ser utilizado por un usuario no especializado a través de los bancos de imágenes si, por ejemplo, ha encontrado una imagen en internet que necesita utilizar, pero de la cual desconoce la fuente y su posible uso legal. Por tanto, los usuarios pueden buscar en lugares fiables, los bancos de imágenes, recursos legales a partir de imágenes que no podría usar de otra forma o también, por ejemplo, de otras imágenes legales de la competencia.

Los estudios sobre los algoritmos y métodos matemáticos de este sistema, como los mencionados (Sarwar et al., 2019; Gu et al., 2020; Tong et al., 2020), muestran que se está avanzando en mejorar la eficacia de este SRI. En este trabajo se va a analizar su efectividad en una muestra de bancos.

\section{Metodología}

Para lograr los objetivos descritos se diseña una investigación basada en la metodología de estudio de caso múltiple (Yin, 2014), así como de análisis e inspección de experto o heurístico (Nielsen y Molich, 1990), para la validación o no de los resultados ofrecidos. Se testea la eficacia en la recuperación tras una búsqueda inversa de una selección de "imágenes icónicas objeto" e "imágenes icónicas escena" (Lin et al., 2014).

La búsqueda se realiza en los bancos que dispongan de sistema de recuperación de imágenes mediante imagen de ejemplo, de entre una muestra de bancos de imágenes seleccionados según su posicionamiento web y su relevancia en la literatura previa (epígrafe 3.2). Para determinar el grado de eficacia de los resultados se Lleva a cabo un análisis e inspección de experto o heurístico de la interfaz y de las imágenes obtenidas tras la consulta para examinar los atributos seleccionados (epígrafe 3.4). Todo ello se desarrolla en dos oleadas con el objeto de analizar una posible evolución: la primera tuvo lugar en octubre de 2018 y la segunda en septiembre 2019.

Con toda la información de bancos, su tipología, sus SRI, imágenes elegidas para la búsqueda inversa, resultados de búsqueda y del análisis de contenido de las imágenes

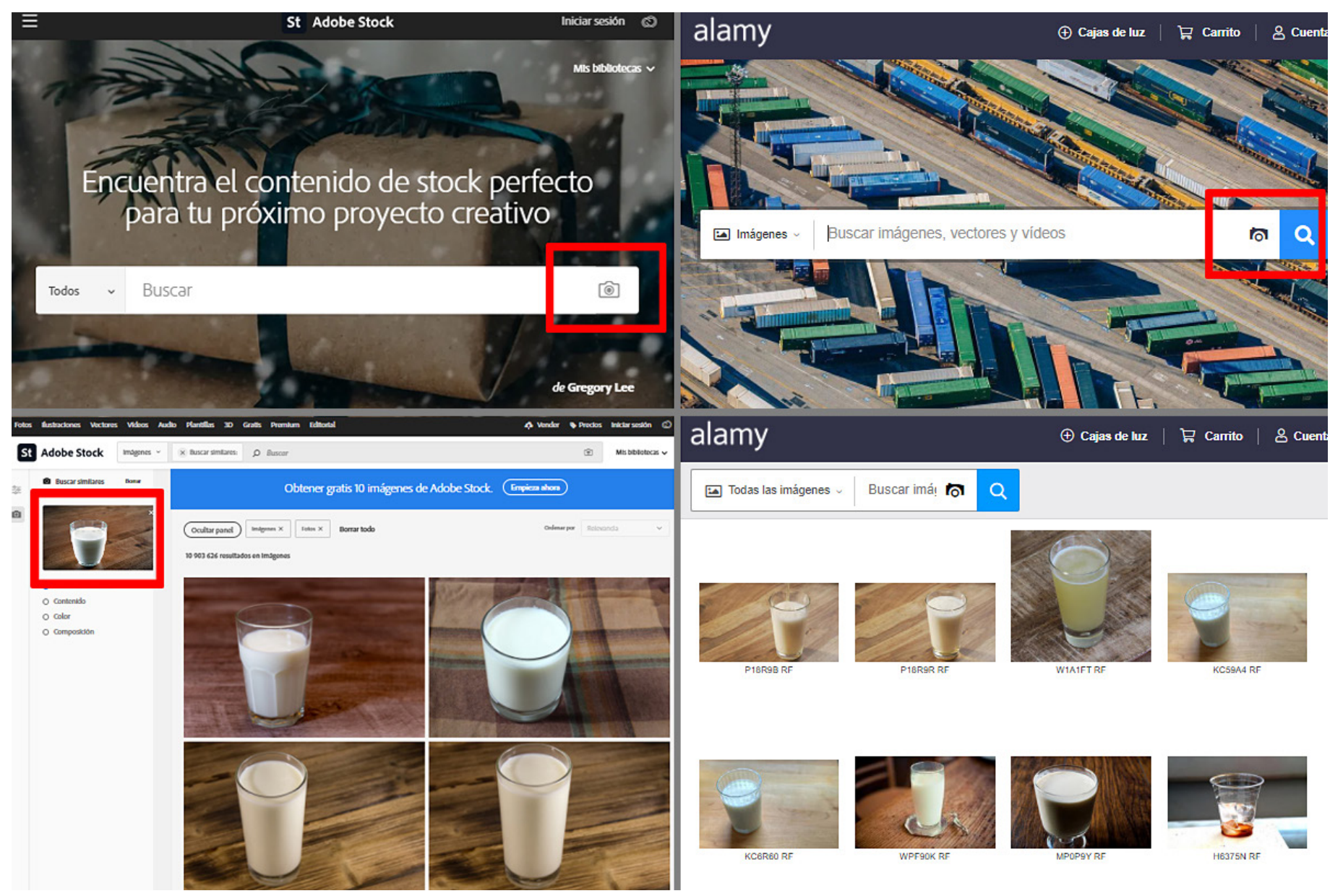

Figura 3. Composición de ejemplos de la búsqueda mediante imágenes (en la parte superior se observa dónde se selecciona y en la parte inferior se muestran los resultados) en Adobe Stock (izquierda) y Alamy (derecha). Fuente: Elaboración propia a partir de sus sitios web 
se crea una base de datos, vinculada a una hoja de cálculo, que sirve para analizar los resultados.

\subsection{Objeto de estudio}

En este trabajo se analizan los bancos de imágenes en internet, por lo que se ha de aclarar que la propia naturaleza del medio implica que el objeto de estudio sea inabarcable en su totalidad, teniendo limitaciones como la propia mutabilidad de internet (Gindin y Busso, 2018), el idioma utilizado o la dificultad del acceso exacto a un banco que no esté bien posicionado en los buscadores. Por tanto, resulta necesaria una selección de los sitios web a analizar.

Dicha inestabilidad del objeto de estudio queda patente en el análisis comparativo realizado entre las dos oleadas. En el trascurso de apenas un año se produjeron cambios, de modo que dos bancos dejaron de estar operativos (de forma independiente) y en otros bancos hubo evolución en cuanto a su funcionalidad (Tabla 4), que era lo que se trataba de analizar en el estudio interanual.

\subsection{Muestra de bancos de imágenes a analizar}

Puesto que la investigación está enfocada hacia la eficacia de los bancos desde el punto de vista de los usuarios finales, y debido a que estos accederán a ellos fundamentalmente a través de buscadores, se recurre al posicionamiento web para una primera selección de bancos, de modo que se consideran los primeros 50 resultados naturales y orgánicos (Maciá y Gosende, 2009; Carreras, 2012) obtenidos del buscador Google, el más utilizado por los internautas (Statcounter, 2020).

Una vez filtrados los resultados (se eliminan duplicidades, así como sitios web que no se pueden catalogar estrictamente como bancos), se añaden otros, no tan bien posicionados pero que, o bien por su trayectoria o por su presencia recurrente en la literatura previa referida (en especial, en los estudios de caso) se consideran que deben formar parte de la muestra.

Los bancos totales seleccionados se exponen en la Tabla 1.

\begin{tabular}{|c|c|c|}
\hline Denominación & Tipología & URL \\
\hline $123 r f$ & comercial & https://es.123rf.com/ \\
\hline $500 p x$ & comercial & $\begin{array}{l}\text { https://500px.com/?lan- } \\
\text { g=es }\end{array}$ \\
\hline Adobe Stock & comercial & $\begin{array}{l}\text { https://stock.adobe.com/ } \\
\text { es/ }\end{array}$ \\
\hline Age Fotostock & comercial & $\begin{array}{l}\text { https://www.agefotostock. } \\
\text { com/age/es/ }\end{array}$ \\
\hline Alamy & comercial & https://www.alamy.es/ \\
\hline
\end{tabular}

\begin{tabular}{|c|c|c|}
\hline Denominación & Tipología & URL \\
\hline Bigstock & comercial & $\begin{array}{l}\text { https://www.bigstoc- } \\
\text { kphoto.com/es/ }\end{array}$ \\
\hline Canstock Photo & comercial & $\begin{array}{l}\text { https://www.canstoc- } \\
\text { kphoto.com/ }\end{array}$ \\
\hline Creative Market & comercial & $\begin{array}{l}\text { https://creativemarket. } \\
\text { com/ }\end{array}$ \\
\hline Crestock & comercial & http://www.crestock.com/ \\
\hline Deposit Photos & comercial & $\begin{array}{l}\text { https://sp.depositphotos. } \\
\text { com/ }\end{array}$ \\
\hline Dreamstime & comercial & $\begin{array}{l}\text { https://es.dreamstime. } \\
\text { com/ }\end{array}$ \\
\hline Epictura & comercial & http://www.epictura.es/ \\
\hline Flickr & gratuito & $\begin{array}{l}\text { https://www.flickr.com/ } \\
\text { commons }\end{array}$ \\
\hline Foter & gratuito & https://foter.com/ \\
\hline Free Images & gratuito & https://es.freeimages.com/ \\
\hline Freedigitalphoto & gratuito & $\begin{array}{l}\text { http://www.freedigitalpho- } \\
\text { tos.net/ }\end{array}$ \\
\hline FreeJPG & gratuito & $\begin{array}{l}\text { http://www.freejpg.com. } \\
\text { ar/?changelang=es }\end{array}$ \\
\hline Freepik & gratuito & https://www.freepik.es/ \\
\hline Freerange & gratuito & $\begin{array}{l}\text { https://freerangestock. } \\
\text { com/ }\end{array}$ \\
\hline Getty Images & comercial & $\begin{array}{l}\text { https://www.gettyimages. } \\
\text { es/ }\end{array}$ \\
\hline Gratisography & gratuito & https://gratisography.com/ \\
\hline IM Free & gratuito & http://imcreator.com/free \\
\hline Ingimage & comercial & $\begin{array}{l}\text { https://www.ingimage. } \\
\text { com/ }\end{array}$ \\
\hline ISO Republic & gratuito & https://isorepublic.com/ \\
\hline iStockphotos & comercial & $\begin{array}{l}\text { https://www.istockphoto. } \\
\text { com/es/ }\end{array}$ \\
\hline Jéshoots & gratuito & https://jeshoots.com/ \\
\hline Kaboompics & gratuito & https://kaboompics.com/ \\
\hline lifeofpix & gratuito & https://www.lifeofpix.com/ \\
\hline Magdeleine & gratuito & https://magdeleine.com/ \\
\hline Negative Space & gratuito & https://negativespace.com/ \\
\hline Pexels & gratuito & https://www.pexels.com/ \\
\hline PhotoGien & gratuito & http://www.photogen.com/ \\
\hline PhotoShelter & comercial & $\begin{array}{l}\text { http://www.photoshelter. } \\
\text { com/referral/YG8SA8PV6J }\end{array}$ \\
\hline Picjumbo & gratuito & https://picjumbo.com/ \\
\hline Picography & comercial & https://picography.co/ \\
\hline Pikwizard & gratuito & https://pikwizard.com/ \\
\hline Pixabay & gratuito & https://pixabay.com/es/ \\
\hline $\begin{array}{l}\text { Public Domain } \\
\text { Picture }\end{array}$ & gratuito & $\begin{array}{l}\text { https://www.publicdo- } \\
\text { mainpictures.net/en/ }\end{array}$ \\
\hline RBG Stock & gratuito & http://www.rgbstock.es/ \\
\hline Refe & gratuito & http://getrefe.com/ \\
\hline
\end{tabular}




\begin{tabular}{|l|l|l|}
\hline Denominación & Tipología & URL \\
\hline Shutterstock & comercial & $\begin{array}{l}\text { https://www.shutterstock. } \\
\text { com/es/ }\end{array}$ \\
\hline Stock photo & comercial & https://stockphoto.com/ \\
\hline Stocklib & comercial & https://www.stocklib.es/ \\
\hline $\begin{array}{l}\text { StockPhotoSe- } \\
\text { crets }\end{array}$ & comercial & $\begin{array}{l}\text { https://shop.stockphotose- } \\
\text { crets.com/ }\end{array}$ \\
\hline StockSanp & gratuito & https://stocksnap.io/ \\
\hline Stockvault & gratuito & $\begin{array}{l}\text { https://www.stockvault. } \\
\text { net/ }\end{array}$ \\
\hline StokPic & gratuito & http://stokpic.com/ \\
\hline Thinkstock & comercial & $\begin{array}{l}\text { http://www.thinkstockpho- } \\
\text { tos.es/search/ }\end{array}$ \\
\hline $\begin{array}{l}\text { Ultra HD Wall- } \\
\text { papers }\end{array}$ & gratuito & https://uhdwallpapers.org/ \\
\hline Unsplash & gratuito & https://unsplash.com/ \\
\hline Veer & comercial & https://www.veer.com/ \\
\hline
\end{tabular}

Tabla 1. Muestra de bancos de imágenes en internet a analizar. Fuente: Elaboración propia.

Este listado constituye la muestra final de 51 bancos seleccionada para la oleada de 2018 , de los cuales 23 son comerciales y 28 gratuitos. En el análisis realizado en 2019, como se ha mencionado, hubo algunos cambios en las empresas y los bancos analizados (Istockphoto ya no lanza las búsquedas sobre sus fondos propios, sino que lo hace sobre los de Getty Images y Thinkstock ya no tiene sitio web específico, sino que su web redirige al sitio de Istockphoto, por tanto, ninguno de los dos es analizado como banco independiente, al ser finalmente lo mismo que buscar en la matriz de Getty Images), quedando la muestra de esa oleada de análisis en 49 bancos de imágenes (21 comerciales y 28 gratuitos).

\subsection{Selección de imágenes a buscar}

Las imágenes seleccionadas para testar el funcionamiento de los sistemas de recuperación de imágenes mediante otras de ejemplo de los bancos se eligieron al azar, bajo las siguientes premisas:

- Se tomaron de internet, en concreto mediante Google, como lo podría haber hecho cualquier usuario tipo (mediante una búsqueda textual sin ninguna limitación, por ejemplo, de tipo de derechos de uso).

- Se pretendió que fueran imágenes con un elemento predominante y reconocible de forma sencilla en la imagen. De este modo, el conjunto de imágenes son imágenes simples, no muy complejas, las ya referi- das "imágenes icónicas objeto" e "imágenes icónicas escena" (Lin et al., 2014).

- El grupo de imágenes debía ser lo suficientemente representativo, por lo que se eligen imágenes de los tres grandes géneros fotográficos clásicos, entendidos como una categoría en la que podemos englobar una serie de imágenes que tienen unas características temáticas y/o formales similares. Por tanto, se eligieron tres imágenes de cada uno de los tres géneros (Tabla 2): paisajes, retratos y bodegones (no se incluye imágenes de otro género que sería el de reportajes, ya que implicaría buscar varias imágenes a la vez -y eso aún no lo permiten los sistemas de búsqueda inversa de los bancos-).

Dentro de la categoría "Paisaje" se pretendió elegir imágenes de distinta índole como una ciudad, un valle y una playa. Además, se procuró incluir ejemplos con un cierto contraste cromático y una variedad de elementos mostrados.

Para la categoría "Bodegones", se buscó imágenes diversas en relación a las formas de los objetos, así como a la variedad de la composición de la textura en el fondo.

En cuanto a la categoría "Retratos", se consideraron los derechos de imagen, por ello no se han seleccionado imágenes en las que aparecieran personas, además de que iban a ser más difíciles de comparar. Se optó por animales diversos, como un mamífero, un ave y un reptil, además de otras características como la captura del movimiento (perro y pájaro) o el predominio de la textura (en el caso de la tortuga).

Para la búsqueda textual complementaria, se realizó una descripción textual de las imágenes seleccionadas, de modo que se realizó la consulta en los bancos según los siguientes términos específicos:

- Paisaje A: "Ciudad de día"

- Paisaje B: "Valle con montañas de día"

- Paisaje C: "Playa de arena de día"

- Bodegón A: "Pelota de tenis sobre pista verde"

- Bodegón B: "Vaso de cristal con leche sobre madera"

- Bodegón C: "Juego de llaves sobre fondo blanco"

- Retrato A: "Perro corriendo sobre césped"

- Retrato B: "Pájaro colibrí volando"

- Retrato C: "Tortuga sobre piedra y hierba"

Las búsquedas textuales se han realizado en español en los casos que el banco ofrece una versión específica en este idioma, en inglés cuando no existía esa versión y en chino en el banco seleccionado que ofrece sus servicios en ese lenguaje. 


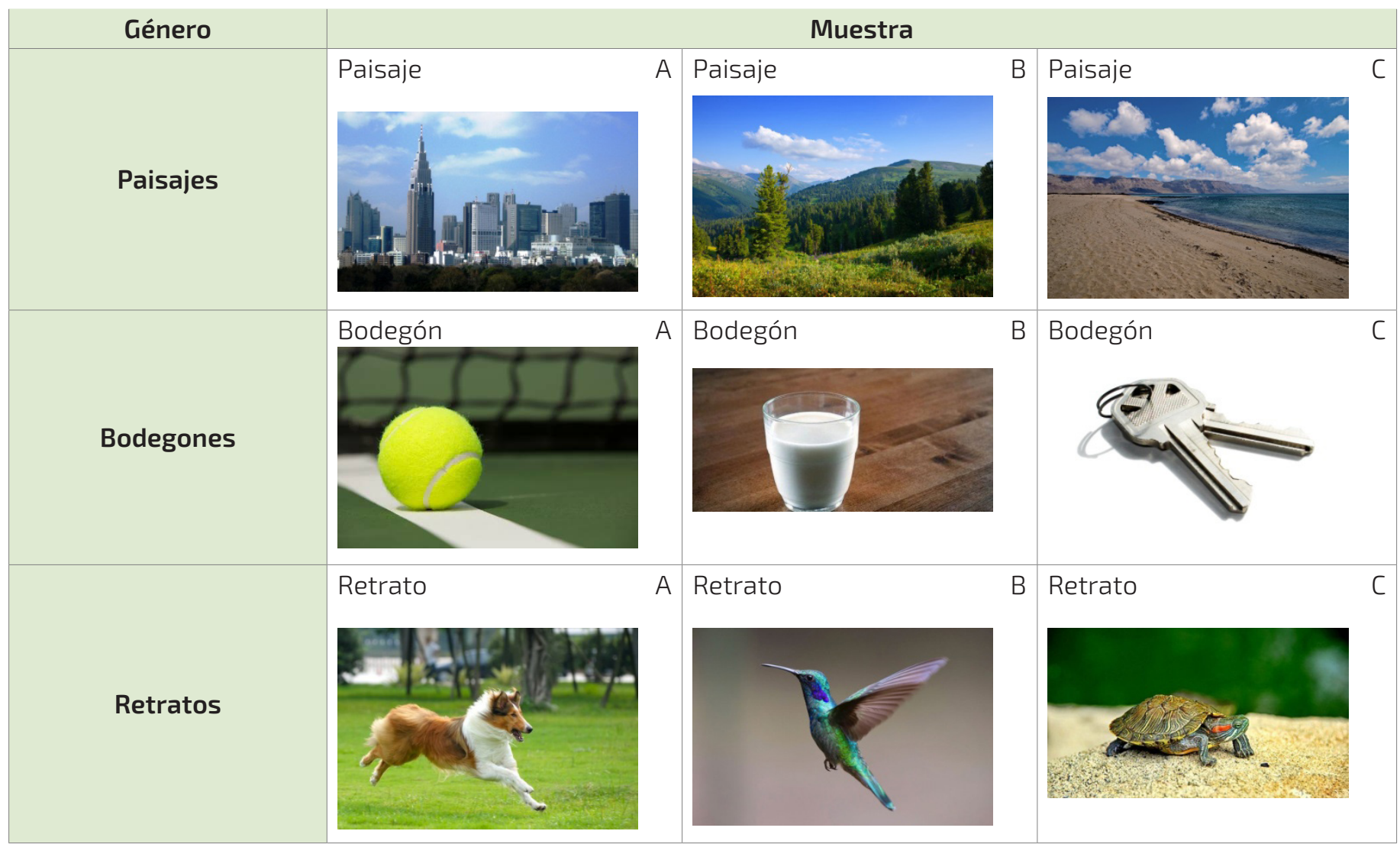

Tabla 2. Matriz de muestra de imágenes. Elaboración propia (matriz). Las fuentes de las imágenes se detallan en el epígrafe de las referencias.

\subsection{Atributos a considerar en las imágenes a comparar}

Una vez se realiza la búsqueda en los bancos, para que las imágenes obtenidas como resultado fueran consideradas como pertinentes $\mathrm{y}$, por tanto, la búsqueda fuera eficaz, se tomaron los siguientes criterios:

- El primero y fundamental es que en la imagen obtenida se mantuviera representado el referente primigenio, es decir, que se produjera una relación de mímesis, de índice, y se reconociera el referente en el sentido clásico (Barthes, 2009; Krauss, 2004; Villafañe, 2001). En definitiva, que se siguiera reconociendo icónicamente el elemento principal presente en la imagen buscada.

- En segundo lugar, que se mantuviera el tipo de resultado "imagen" (se descartaron vídeos, ilustraciones e imágenes animadas).

- En tercer lugar, se establecen una serie de facetas, características intrínsecas de las imágenes o características de bajo nivel que tuvieron que cumplir los resultados, siendo estas: color, textura y forma. En la Tabla 3 se puede observar un ejemplo de dichas características aplicada en una imagen de la muestra.

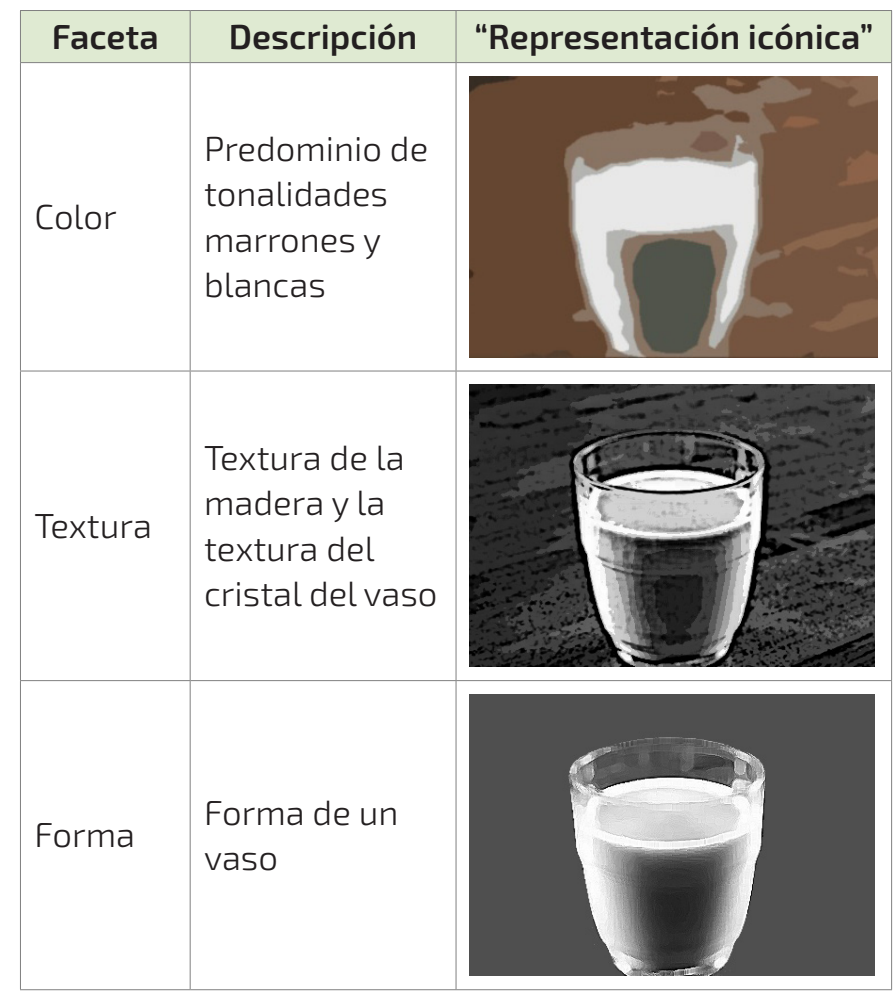

Tabla 3. Ejemplo de características de bajo nivel a analizar en los resultados tras la consulta mediante la imagen "bodegón B". Fuente: Elaboración propia a partir de la imagen original citada en las Referencias. 
Se consideraron como resultados pertinentes las imágenes de las que se reconocía el referente, se mantenía el tipo de "imagen" y al menos dos de las características de bajo nivel (color, textura y forma). Como los bancos de imágenes suelen ofrecer en forma de mosaico cientos o miles de resultados por cada búsqueda, se estableció una "imagen de corte", hasta la cual se determinó que las imágenes obtenidas eran pertinentes y, a partir de la cual, se detuvo el análisis de contenido de las imágenes (no hubiera sido viable analizar la totalidad de resultados de la búsqueda de cada una de las nueve imágenes en todos los bancos objeto de estudio).

El grado de efectividad de la consulta se midió en porcentaje, obtenido del número de imágenes consideradas como válidas (anteriores a la imagen de corte) sobre el número total de resultados ofrecidos por el banco.

\subsection{Limitaciones}

Dado que este estudio se realiza en bancos de imágenes en internet, con una arquitectura informática compleja y que utiliza lenguajes y sistemas de inteligencia artificial que van evolucionando, se ha de tener en cuenta que los resultados obtenidos en este estudio es probable que varíen si se replica la investigación. Además de lo descrito, al tratarse de bancos de imágenes en uso, se puede producir la obtención de nuevos resultados, como consecuencia de la incorporación de nuevos fondos, o la eliminación de parte de los mismos, por tanto, las imágenes de corte que determinan los resultados es muy posible que fueran diferentes en futuras búsquedas.

Asimismo, hay que considerar la volatilidad de los bancos de imágenes. Es frecuente que desaparezcan o incluso se lleven a cabo fusiones; así como la eliminación en los bancos de imágenes de algún SRI y la utilización de otros.

El idioma es un requisito fundamental para una correcta búsqueda y recuperación, por ello hay que tener en cuenta que existen bancos de imágenes que priorizan un determinado idioma o que no admiten varios idiomas en sus búsquedas, como ha sido el caso de Veer, en el que las consultan han tenido que ser traducidas al chino y, por tanto, su precisión conceptual puede no ser idéntica a la del idioma original.

Por último, hay que señalar que las imágenes de corte propuestas están sometidas a la subjetividad del análisis de los investigadores de las características de bajo nivel. Los datos aceptados y, por tanto, relevantes son aquellos que cumplen dos de las tres variables ya descritas: textura, color y forma. No obstante, la valoración ciertamente subjetiva de estas características se ha llevado a cabo en todos los bancos por igual y de la forma más ecuánime posible. En los casos que no quedaba clara la imagen de corte, se recurrió a realizar el análisis por ambos investigadores con el objeto de consensuarla. De este modo, mediante la intersubjetividad, se paliaba el componente subjetivo mencionado.

A pesar de estas limitaciones, esta investigación se considera de interés porque permite conocer la eficacia de los sistemas de recuperación en el momento del análisis, bajo las condiciones expuestas. Además, resultará igualmente útil para futuros análisis comparativos.

\section{Resultados y Discusión}

Al analizar los SRI que ofrece cada banco de imágenes objeto de análisis, los resultados que se obtienen son los que se muestran en la Tabla 4. En cada oleada de análisis, 2018 (columnas 3-5) y 2019 (columnas 6-8), se incluye tres columnas y se indica (1=sí / 0=no) si cada banco ofrece SRI textual, por facetas/filtros o mediante imagen de muestra, según se han definido en el marco teórico.

Se puede apreciar que, de los 51 bancos estudiados en 2018, casi todos (48) incluyen el SRI textual, sistema de consulta al que los usuarios están especialmente acostumbrados por su utilización habitual en el buscador Google. Resulta bastante extraño que los tres bancos restantes no ofrezcan esa posibilidad, si se considera que es una funcionalidad sencilla de implementar.

Son 14 bancos los que incluyen el sistema de búsqueda por facetas o filtros. Hay que recordar que esta función debe estar ya presente en el momento de la consulta (no a posteriori, tras mostrar los resultados, lo que se consideraría retroalimentación, no consulta).

Los bancos que en 2018 incluyen entre sus SRI la consulta mediante imágenes de ejemplo son 9 de 51 (el 17,6\% del total de la muestra). Son: 123rf, Adobe Stock, Deposit Photos, Getty Images, Ingimage, iStockphotos, Shutterstock, StockPhotoSecrets y Veer. Se podría decir que es una cifra baja, pero hay que considerar que esta funcionalidad implica una inversión que no todos los bancos se pueden permitir. Además, si se observa la tipología de los bancos, se puede apreciar que la totalidad de bancos que incluyen este sistema de recuperación son comerciales (de pago), de modo que, si no se consideran los bancos gratuitos, el porcentaje de bancos (comerciales) que incluyen este sistema de búsqueda ascendería al 39,1\% (9 de 23).

En la evolución interanual se observa que dos bancos (iStockphotos y Thinkstock) en 2019 no son consultables como bancos independientes, por lo que la muestra 


\begin{tabular}{|c|c|c|c|c|c|c|c|}
\hline \multirow[t]{2}{*}{ Banco de imágenes } & \multirow[t]{2}{*}{ Tipología } & \multicolumn{3}{|c|}{ SRI (2018) } & \multicolumn{3}{|c|}{ SRI (2019) } \\
\hline & & Textual & Facetas/filtros & Imagen & Textual & Facetas/filtros & Imagen \\
\hline $500 p x$ & C & 1 & 0 & 0 & 1 & 0 & 0 \\
\hline Age Fotostock & C & 1 & 0 & 0 & 1 & 0 & 0 \\
\hline Bigstock & C & 1 & 0 & 0 & 1 & 0 & 0 \\
\hline Canstock Photo & C & 1 & 0 & 0 & 1 & 0 & 0 \\
\hline Creative Market & C & 1 & 0 & 0 & 1 & 0 & 0 \\
\hline Dreamstime & C & 1 & 0 & 0 & 1 & 0 & $1 * *$ \\
\hline Picography & C & 1 & 0 & 0 & 1 & 0 & 0 \\
\hline Alamy & C & 1 & 1 & 0 & 1 & 1 & 1 ** \\
\hline Crestock & C & 1 & 1 & 0 & 1 & 1 & 0 \\
\hline Epictura & C & 1 & 1 & 0 & 1 & 1 & 0 \\
\hline PhotoShelter & C & 1 & 1 & 0 & 1 & 1 & 0 \\
\hline Stock photo & C & 1 & 1 & 0 & 1 & 1 & 0 \\
\hline Stocklib & C & 1 & 1 & 0 & 1 & 1 & 0 \\
\hline Thinkstock* & C & 1 & 1 & 0 & - & - & - \\
\hline $123 r f$ & C & 1 & 0 & 1 & 1 & 0 & 1 \\
\hline Adobe Stock & C & 1 & 0 & 1 & 1 & 0 & 1 \\
\hline Deposit Photos & C & 1 & 0 & 1 & 1 & 0 & 1 \\
\hline Getty Images & C & 1 & 0 & 1 & 1 & 0 & 1 \\
\hline Ingimage & C & 1 & 0 & 1 & 1 & 0 & 1 \\
\hline iStockphotos* & C & 1 & 0 & 1 & - & - & - \\
\hline Shutterstock & C & 1 & 0 & 1 & 1 & 0 & 1 \\
\hline StockPhotoSecrets & C & 1 & 0 & 1 & 1 & 0 & 1 \\
\hline Veer & C & 1 & 0 & 1 & 1 & 0 & 1 \\
\hline Jéshoots & g & 0 & 1 & 0 & 0 & 1 & 0 \\
\hline Magdeleine & g & 0 & 1 & 0 & 0 & 1 & 0 \\
\hline Refe & g & 0 & 1 & 0 & 0 & 1 & 0 \\
\hline Free Images & g & 1 & 0 & 0 & 1 & 0 & 0 \\
\hline Freedigitalphoto & g & 1 & 0 & 0 & 1 & 0 & 0 \\
\hline FreeJPG & g & 1 & 0 & 0 & 1 & 0 & 0 \\
\hline Freepik & g & 1 & 0 & 0 & 1 & 0 & 0 \\
\hline Freerange & g & 1 & 0 & 0 & 1 & 0 & 0 \\
\hline Gratisography & g & 1 & 0 & 0 & 1 & 0 & 0 \\
\hline IM Free & g & 1 & 0 & 0 & 1 & 0 & 0 \\
\hline ISO Republic & g & 1 & 0 & 0 & 1 & 0 & 0 \\
\hline Kaboompics & g & 1 & 0 & 0 & 1 & 0 & 0 \\
\hline Lifeofpix & g & 1 & 0 & 0 & 1 & 0 & 0 \\
\hline Negative Space & g & 1 & 0 & 0 & 1 & 0 & 0 \\
\hline Pexels & g & 1 & 0 & 0 & 1 & 0 & 0 \\
\hline Picjumbo & g & 1 & 0 & 0 & 1 & 0 & 0 \\
\hline Pikwizard & g & 1 & 0 & 0 & 1 & 0 & 0 \\
\hline Pixabay & g & 1 & 0 & 0 & 1 & 0 & 0 \\
\hline Public Domain Picture & g & 1 & 0 & 0 & 1 & 0 & 0 \\
\hline RBG Stock & g & 1 & 0 & 0 & 1 & 0 & 0 \\
\hline StockSanp & g & 1 & 0 & 0 & 1 & 0 & 0 \\
\hline Stockvault & g & 1 & 0 & 0 & 1 & 0 & 0 \\
\hline
\end{tabular}




\begin{tabular}{|l|l|l|l|l|l|l|l|}
\hline \multirow{2}{*}{ Banco de imágenes } & Tipología & \multicolumn{9}{|c|}{ SRI (2018) } & \multicolumn{3}{c|}{ SRI (2019) } \\
\cline { 3 - 8 } & & Textual & Facetas/filtros & Imagen & Textual & Facetas/filtros & Imagen \\
\hline StokPic & $\mathrm{g}$ & 1 & 0 & 0 & 1 & 0 & 0 \\
\hline Unsplash & $\mathrm{g}$ & 1 & 0 & 0 & 1 & 0 & 0 \\
\hline Flickr & $\mathrm{g}$ & 1 & 1 & 0 & 1 & 1 & 0 \\
\hline Foter & $\mathrm{g}$ & 1 & 1 & 0 & 1 & 1 & 0 \\
\hline PhotoGien & $\mathrm{g}$ & 1 & 1 & 0 & 1 & 1 & 0 \\
\hline Ultra HD Wallpapers & $\mathrm{g}$ & 1 & 1 & 0 & 1 & 1 & 0 \\
\hline TOTAL & & $\mathbf{4 8}$ & $\mathbf{1 4}$ & $\mathbf{9}$ & $\mathbf{4 6}$ & $\mathbf{1 3}$ & $\mathbf{1 0}$ \\
\hline
\end{tabular}

* No consultables en oleada de 2019. **Se añade SRI

Tipología: C (comercial) - g (gratuito). Valores: 0 (No) - 1 (Sí).

Tabla 4. Sistemas de recuperación de imágenes incluidos en cada banco de la muestra en las dos oleadas (2018 y 2019$)$. Fuente: Elaboración propia.

pasa de 51 bancos en 2018 a 49 un año después. Estos dos bancos incluían el SRI textual, por lo que desciende ese valor en 2019, al igual que una unidad en el SRI por facetas correspondiente al banco Thinkstock y una unidad en el SRI mediante imagen de ejemplo de iStockphotos. El resto de valores se mantienen salvo dos casos: tanto Alamy como Dreamstime han incluido el SRI mediante imagen de ejemplo en sus funcionalidades. De esta forma, la muestra final en 2019 de bancos que incluyen el SRI mediante imagen de ejemplo la forman 10 bancos de 49 (20,4\%): 123rf, Adobe Stock, Alamy, Deposit Photos, Dreamstime, Getty Images, Ingimage, Shutterstock, StockPhotoSecrets y Veer. Por tanto, se observa que en apenas un año ha habido interés por incorporar esa funcionalidad (casi la mitad, el 47,6\%, de los comerciales ya lo incluía). No se puede decir que los datos indiquen que es una tendencia, pero sí que parece que esa es la dirección a tomar por los bancos de imágenes comerciales, extremo que habrá que confirmar en futuras investigaciones.

Se puede ver en la Figura 4 que sí hay diferencia en cuanto al número de SRI que ofrecen estos sitios web dependiendo de si los bancos de imágenes son comerciales o gratuitos. Se observa en los gratuitos que la mayoría (24, que supone el $85,7 \%$ ) ofrece un único tipo de SRI (21 bancos SRI textual y 3 SRI por facetas), mientras que sólo el 14,3\% restante ofrece dos sistemas (textual y por facetas). Sin embargo, en los bancos comerciales, es mayor el número de bancos que ofrecen dos sistemas ( 16 bancos, casi el 70\%) que los que ofrecen uno (los 7 bancos que ofrecen el SRI textual exclusivamente). De los que ofrecen dos sistemas, 7 ofrecen el textual y por facetas y 9 el textual y el SRI mediante imagen de ejemplo (datos de la oleada de 2018). Y es un banco comercial, Alamy, el único que ofrece tres SRI tras incorporar en 2019 la consulta mediante imagen de ejemplo. Los bancos de imágenes comerciales han de esforzarse en dar el mejor servicio posible a sus usuarios ya que hay una gran competencia en el sector, de ahí que inviertan en incluir diversos $\mathrm{SRI}$, en que los resultados de las consultas sean eficaces y, para ello, trabajan en constantes mejoras como la implementación de la búsqueda inversa. Un buen ejemplo de ello es el mencionado de Alamy, que ha incluido el sistema en 2019 y, además, es de los más eficaces (como se puede observar a continuación).

Los resultados relacionados con el objetivo principal, evaluar la eficacia de la búsqueda inversa de imágenes se muestras en la Tabla 5.

Se puede observar que el porcentaje de eficiencia es bastante dispar en función del banco, del género fotográfico, de la imagen, incluso de la oleada de análisis. No hay diferencias sustanciales de unos bancos a otros, aunque sí destacan los bancos Deposit Photos, Getty Images y Veer, que ofrecen porcentajes muy altos en el género paisaje, aunque, sin embargo, los porcentajes bajan notablemente en otro tipo de imágenes. Es probable que esta alta eficiencia se deba a que las imágenes

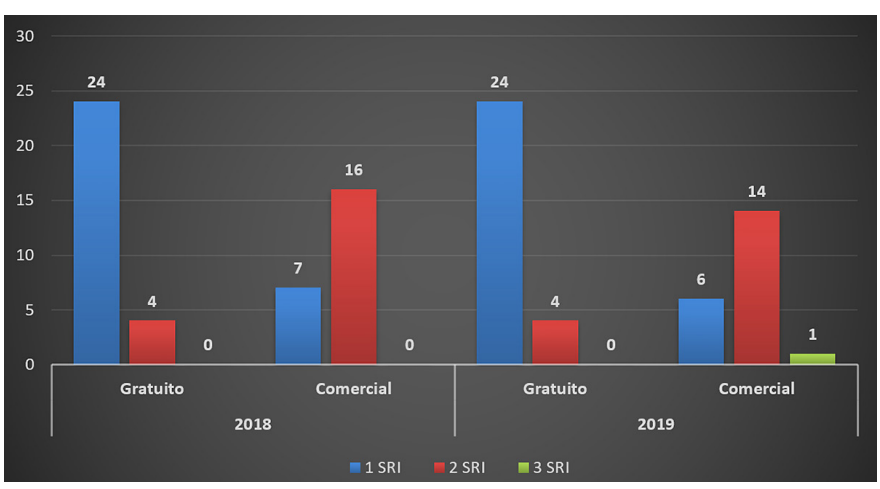

Figura 4. Número de SRI incluidos en cada banco según la tipología y el año de análisis. Fuente: Elaboración propia. 
de paisajes sean más "sencillas" en cuanto a los elementos de perfil bajo objeto de análisis.

Destaca Alamy como banco que es 100\% eficaz, tanto en los tres paisajes, como en dos de los tres retratos. En este último género es casi el único banco que alcanza esas cifras tan altas (junto con Deposit Photos, con casi un $97 \%$ de eficiencia en la consulta del retrato A en 2019 , y que, sin embargo, en los otros dos retratos obtiene porcentajes mucho menores).

Hay que aclarar que los pésimos valores generales obtenidos en el banco Adobe Stock se deben a que el porcentaje se calcula partiendo de las imágenes pertinentes sobre el número total de imágenes mostradas tras la consulta. Este banco en unos pocos casos directamente no ofrecía resultados, y en todos los que sí los ofrecía, el número de imágenes mostradas tras la consulta siempre se correspondía con el número total de imágenes de los fondos del banco, de ahí que casi todos los valores sean o estén muy próximos al cero. Ha sido el único banco que no cuantificaba el conjunto de imágenes seleccionadas respecto al total existente. No obstante, se ha decidido ofrecer los datos en la tabla 5 , si bien no han sido considerados para calcular valores medios de todos los bancos (pues hubiera bajado los valores medios de manera significativa).

Para hacer un análisis detallado por imágenes, por género fotográfico y de la evolución interanual (20182019), se calculó la media de todos los bancos (sin contabilizar los datos de Adobe Stock). Los porcentajes medios de eficiencia por imagen buscada y año se ofrecen en la Figura 5.

Salvo en los casos de las imágenes "paisaje B" y "retrato B", el porcentaje de eficiencia fue superior en la oleada de 2019 que en la 2018, lo que implica mejoras en los sistemas de recuperación de los bancos objeto de análisis. El porcentaje medio total de eficiencia en la recuperación del año 2018 fue de un 21,88\%, mientras que en 2019 fue de un 30,44\%, lo que se estima como un incremento notable en un periodo de apenas un año entre oleadas de análisis.

Por géneros fotográficos, se aprecia mayor efectividad en el paisaje con un 56,83\% de efectividad media. Con valores muy inferiores le siguen el género del retrato con un $13,33 \%$ y, por último, el bodegón con 8,33\%. Es probable que el porcentaje sea mayor en la categoría de paisajes porque la variabilidad de los atributos (color, textura y forma) es menor respecto a los de las otras categorías. Además, las imágenes de paisajes suelen ser estructuralmente más simples (Villafañe, 2001) que los bodegones o los retratos, por tanto, parecen ser más fáciles de buscar comparativamente.

Respecto a la búsqueda textual complementaria que se realizó, se muestran los resultados de forma comparativa con la búsqueda visual en la Tabla 6.

La obtención de unos resultados tan pobres en la búsqueda textual se debe sin duda a que en la consulta se buscaba un grupo de términos muy concreto, a los que el banco no pudo dar respuesta, todo ello consecuencia de tener ya una imagen que se quería buscar mediante

Tabla V. Porcentajes de efectividad de las búsquedas desglosados por banco, imagen y oleada de análisis (2018 - 2019)

\begin{tabular}{|c|c|c|c|c|c|c|c|c|c|c|c|c|c|c|c|c|c|c|}
\hline & 2018 & 2019 & 2018 & 2019 & 2018 & 2019 & 2018 & 2019 & 2018 & 2019 & 2018 & 2019 & 2018 & 2019 & 2018 & 2019 & 2018 & 2019 \\
\hline Denominación & \multicolumn{2}{|c|}{ Paisaje A } & \multicolumn{2}{|c|}{ Paisaje B } & \multicolumn{2}{|c|}{ Paisaje C } & \multicolumn{2}{|c|}{ Bodegón A } & \multicolumn{2}{|c|}{ Bodegón B } & \multicolumn{2}{|c|}{ Bodegón C } & \multicolumn{2}{|c|}{ Retrato $A$} & \multicolumn{2}{|c|}{ Retrato B } & \multicolumn{2}{|c|}{ Retrato C } \\
\hline $123 r f$ & $11,00 \%$ & $0,00 \%$ & $100,00 \%$ & $99,00 \%$ & $0,00 \%$ & $0,00 \%$ & $1,00 \%$ & $12,00 \%$ & $1,00 \%$ & $0,00 \%$ & $1,00 \%$ & $0,00 \%$ & $3,00 \%$ & $0,00 \%$ & $0,00 \%$ & $5,00 \%$ & $1,00 \%$ & $0,00 \%$ \\
\hline Adobe Stock & $0,00 \%$ & $0,01 \%$ & $100,00 \%$ & $0,01 \%$ & $0,00 \%$ & $0,00 \%$ & $0,00 \%$ & $0,00 \%$ & $0,00 \%$ & $0,00 \%$ & $0,00 \%$ & $0,00 \%$ & $0,00 \%$ & $0,00 \%$ & $0,00 \%$ & $0,00 \%$ & $0,00 \%$ & $0,00 \%$ \\
\hline Alamy ** & - & $100,00 \%$ & -- & $100,00 \%$ & - & $100,00 \%$ & -- & $42,00 \%$ & - & $6,00 \%$ & --- & $3,00 \%$ & - & $100,00 \%$ & -- & $8,00 \%$ & - & $100,00 \%$ \\
\hline Deposit Photos & $76,67 \%$ & $96,67 \%$ & $100,00 \%$ & $100,00 \%$ & $100,00 \%$ & $100,00 \%$ & $25,00 \%$ & $58,33 \%$ & $6,67 \%$ & $15,00 \%$ & $1,67 \%$ & $16,67 \%$ & $48,33 \%$ & $96,67 \%$ & $28,33 \%$ & $10,00 \%$ & $6,67 \%$ & $25,00 \%$ \\
\hline Dreamstime ** & -- & $0,00 \%$ & -- & $0,00 \%$ & --- & $0,00 \%$ & -- & $0,00 \%$ & -- & $0,00 \%$ & $\ldots$ & $0,00 \%$ & -- & $0,00 \%$ & -- & $7,14 \%$ & -- & $0,00 \%$ \\
\hline Getty Images & $100,00 \%$ & $100,00 \%$ & $100,00 \%$ & $100,00 \%$ & $20,00 \%$ & $100,00 \%$ & $4,00 \%$ & $2,00 \%$ & $0,00 \%$ & $0,00 \%$ & $0,00 \%$ & $0,00 \%$ & $2,00 \%$ & $33,00 \%$ & $0,00 \%$ & $28,00 \%$ & $9,00 \%$ & $25,00 \%$ \\
\hline Ingimage & $1,10 \%$ & $7,50 \%$ & $7,20 \%$ & $10,40 \%$ & $2,90 \%$ & $10,20 \%$ & $0,80 \%$ & $0,70 \%$ & $0,00 \%$ & $0,10 \%$ & $0,00 \%$ & $0,00 \%$ & $0,10 \%$ & $0,70 \%$ & $0,00 \%$ & $0,10 \%$ & $0,10 \%$ & $0,10 \%$ \\
\hline iStockphotos * & $27,00 \%$ & -- & $100,00 \%$ & -- & $71,00 \%$ & -- & $5,00 \%$ & -- & $0,00 \%$ & -- & $0,00 \%$ & --. & $7,00 \%$ & -- & $26,00 \%$ & -- & $0,00 \%$ & --- \\
\hline Shutterstock & $12,00 \%$ & $70,00 \%$ & $100,00 \%$ & $98,00 \%$ & $97,00 \%$ & $98,00 \%$ & $5,00 \%$ & $64,00 \%$ & $10,00 \%$ & $37,00 \%$ & $1,00 \%$ & $1,00 \%$ & $4,00 \%$ & $13,00 \%$ & $25,00 \%$ & $22,00 \%$ & $0,00 \%$ & $0,00 \%$ \\
\hline StockPhotoSecrets & $4,40 \%$ & $5,90 \%$ & $7,60 \%$ & $11,10 \%$ & $2,50 \%$ & $5,00 \%$ & $0,80 \%$ & $0,70 \%$ & $0,00 \%$ & $0,10 \%$ & $0,00 \%$ & $0,00 \%$ & $0,00 \%$ & $0,70 \%$ & $0,00 \%$ & $0,10 \%$ & $0,10 \%$ & $0,10 \%$ \\
\hline Veer & $98,00 \%$ & $99,00 \%$ & $92,00 \%$ & $98,00 \%$ & $68,00 \%$ & $99,00 \%$ & $10,00 \%$ & $30,00 \%$ & $0,00 \%$ & $0,00 \%$ & $26,00 \%$ & $64,00 \%$ & $11,00 \%$ & $20,00 \%$ & $15,00 \%$ & $15,00 \%$ & $0,00 \%$ & $1,00 \%$ \\
\hline
\end{tabular}

Tabla 5. Porcentajes de efectividad de las búsquedas desglosados por banco, imagen y oleada de análisis (2018 - 2019$)$. Fuente: elaboración propia.

* Solo accesible en la oleada de 2018.

** Solo dispone de SRI mediante imagen de ejemplo a partir de 2019. 


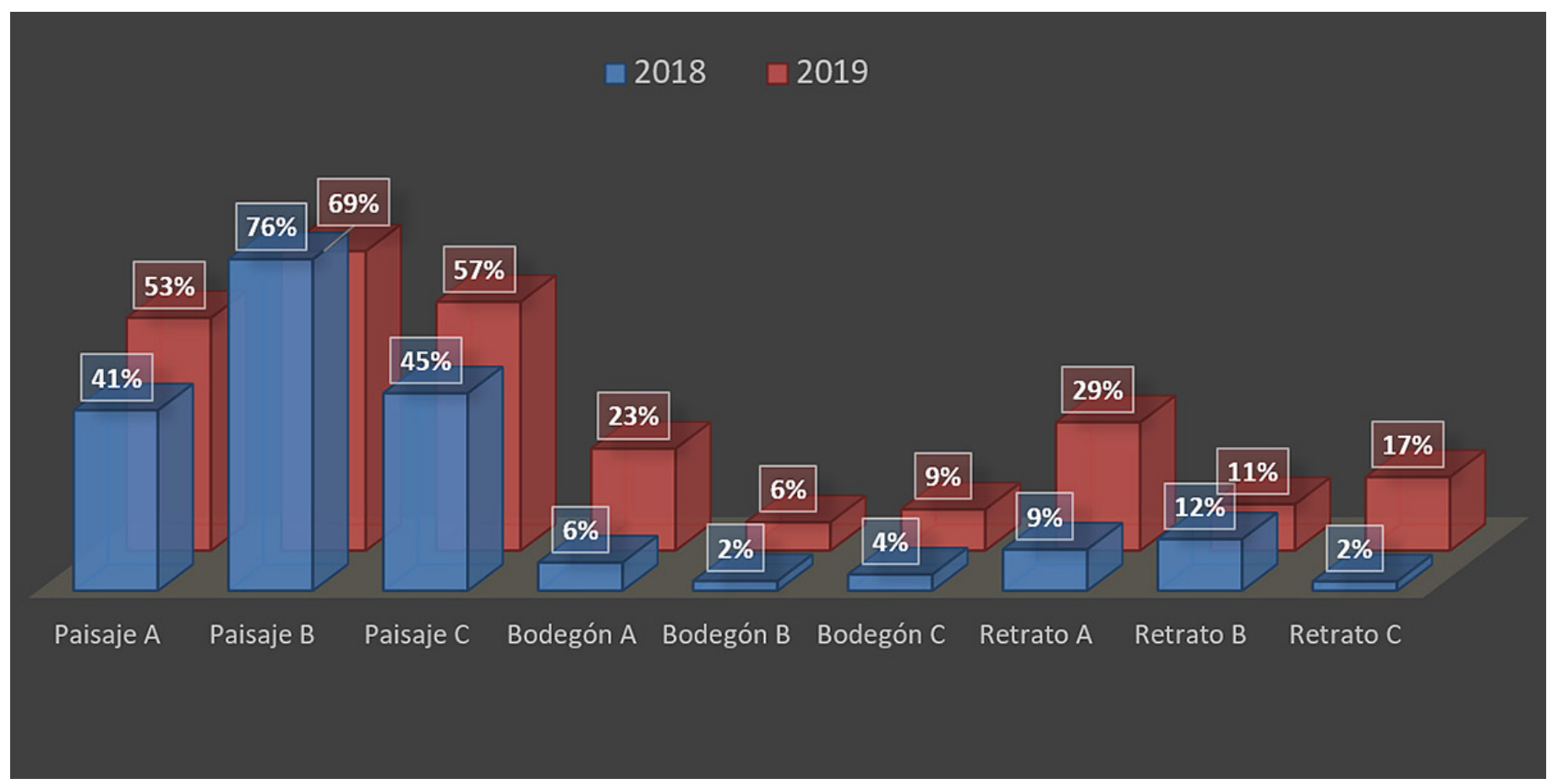

Figura 5. Porcentajes medios de eficiencia por imagen buscada y año. Fuente: Elaboración propia.

su descripción exacta textual. Sin embargo, estos sistemas de recuperación textual se suelen utilizar para realizar consultas sin disponer de una imagen previa, tan solo una idea de lo que se quiere buscary, por tanto, las pesquisas suelen ser mediante un único término o dos, pero no de varios.

\section{Conclusiones}

Tras el análisis de los resultados obtenidos del estudio de los sistemas de recuperación de imágenes que incluyen los bancos, relacionado con el objetivo específico de estudiar dichos sistemas de los bancos, se concluye que no es frecuente que los bancos de imágenes, en general, incluyan la función de búsqueda inversa de imágenes (el 19\% de los analizados). Lo que sí es habitual es que estos sitios incluyan un único SRI, siendo el más común el textual. Esto es así especialmente en los bancos gratuitos. Sin embargo, si el análisis se centra en los bancos con fines comerciales, es más frecuente que incluyan dos SRI, siendo en ocasiones textual y por facetas y en otras ocasiones textual y mediante imagen de ejemplo. Por tanto, la tipología de banco de imágenes sí influye en el número y el tipo de SRI que incluyen. La posibilidad de la búsqueda inversa de imágenes sólo la ofrecen los bancos de imágenes comerciales y no todos (el 39,1\% en la oleada de 2018 y el 47,6\% en la de 2019). No obstante, parece que hay interés en los bancos comerciales en ir implantando esta funcionalidad.

El objetivo principal del estudio era evaluar la eficacia de la búsqueda inversa de los bancos comerciales y, tras haber testado dichos sitios de la muestra con las imágenes de ejemplo, se concluye que los resultados son bastante positivos en este tipo de imágenes si son del género fotográfico paisaje, pero no tan positivos en los otros casos analizados. En general, se podría afirmar que funcionan bastante bien en imágenes estructuralmente simples, mientras que en imágenes algo más complejas a nivel estructural estos SRI tienen aún que mejorar bastante. A pesar de ello, se pone de manifiesto

\begin{tabular}{|c|c|c|c|c|c|c|c|c|c|c|}
\hline Año & SRI & Paisaje A & Paisaje B & Paisaje C & $\begin{array}{l}\text { Bodegón } \\
\text { A }\end{array}$ & $\begin{array}{l}\text { Bodegón } \\
\text { B }\end{array}$ & $\begin{array}{l}\text { Bodegón } \\
\text { C }\end{array}$ & $\begin{array}{l}\text { Retrato } \\
\text { A }\end{array}$ & $\begin{array}{l}\text { Retrato } \\
\text { B }\end{array}$ & Retrato C \\
\hline \multirow{2}{*}{2018} & Textual & $0,002 \%$ & $0,015 \%$ & $0,003 \%$ & $0,000 \%$ & $0,001 \%$ & $0,002 \%$ & $0,757 \%$ & $0,001 \%$ & $0,001 \%$ \\
\hline & Visual & $41,271 \%$ & $75,850 \%$ & $45,175 \%$ & $6,450 \%$ & 208\% & $3,708 \%$ & $9,429 \%$ & $11,792 \%$ & $2,108 \%$ \\
\hline \multirow{2}{*}{2019} & Textual & $0,000 \%$ & $0,004 \%$ & $0,003 \%$ & $0,000 \%$ & $0,000 \%$ & $0,000 \%$ & $0,158 \%$ & $0,001 \%$ & $0,011 \%$ \\
\hline & Visual & $53,230 \%$ & $68,500 \%$ & $56,911 \%$ & $23,304 \%$ & $6,467 \%$ & $9,407 \%$ & $29,341 \%$ & $10,594 \%$ & $16,800 \%$ \\
\hline
\end{tabular}

Tabla 6. Comparativa de porcentajes medios de efectividad textual y visual, desglosados por imagen y año (oleada). Fuente: Elaboración propia. 
que hay sistemas que dan muy buenos resultados, como es el caso del incluido en Alamy, con resultados óptimos en la mayoría de categorías. Por tanto, parece que los sistemas de recuperación mediante imágenes de ejemplo evolucionan y se van haciendo más efectivos, al menos en un primer momento, para una búsqueda de imágenes no muy complejas estructuralmente y no semánticas (Martínez, 2013).

En relación al objetivo de averiguar si existe alguna diferencia en la eficacia de la búsqueda inversa en función de la tipología de los bancos, se concluye que no hay diferencias porque los únicos que incluyen este tipo de consulta son los comerciales. Se podría intentar establecer alguna matización si se determinan los bancos comerciales que se podrían considerar como de microstock y los que son de macrostock, pero hoy en día resulta muy difícil determinar esa diferenciación porque se ha producido una hibridación entre ambos, de modo que los grandes bancos de macrostock, de larga trayectoria, han apostado en los últimos años por ofrecer servicios de microstock (o incluso por comprar bancos de este tipo y adherirlos a la matriz, como ha sido el caso de Getty Images). De forma paralela, los bancos inicialmente de microstock han ido alcanzando acuerdos con los de macrostock para incluir entre sus fondos imágenes auspiciadas o patrocinadas de gran calidad (que suelen priorizar entre los resultados ofreciéndolas al comienzo de los mismos, en la parte superior).

La búsqueda textual que se realizó como complemento a la inversa no arrojó resultados positivos, seguramente porque el conjunto de términos a consultar era muy específico y bastante numeroso, ya que se trataba de una descripción exacta de una imagen concreta. Se puede concluir que búsquedas tan precisas con varios términos no suelen ser fructuosas en los bancos de imágenes. Sin embargo, esto no significa que las consultas mediante el SRI textual sean siempre tan poco eficaces, ya que el usuario tipo normalmente realizará una búsqueda mediante uno o dos términos, la cual, probablemente, sí le reportará numerosos resultados satisfactorios.

Por último, relacionado con el objetivo de realizar un estudio comparativo de las dos oleadas de análisis, no se ha observado una gran evolución, tal y como era previsible, dado el corto periodo de tiempo entre ellas. No obstante, como ya se ha mencionado, sí que se ha constatado la implementación de SRI mediante imagen de ejemplo en dos bancos comerciales, lo que muestra el interés por este sistema. También, el hecho de que haya habido cambios en los bancos confirma lo que ha venido siendo la tónica de las últimas dos décadas en este ámbito: el surgimiento de nuevo bancos y la des- aparición de otros debido, casi siempre, a compras y absorciones por parte de otros mayores.

\section{Agradecimientos}

Los autores quieren dejar constancia de su agradecimiento a los revisores de este trabajo por sus sugerencias y recomendaciones, las cuales han contribuido a la mejora del artículo final.

\section{Financiación}

Este trabajo ha sido financiado en parte mediante la ayuda a la investigación (GR18042/2018) de la Junta de Extremadura (Consejería de Economía, Ciencia y Agenda Digital) y por la Unión Europea "Fondo Europeo de Desarrollo Regional. Una manera de hacer Europa".

\section{Referencias}

Adrakatti, A.F., Wodeyar, R.S., y Mulla, K.R. (2016). Search by Image: A Novel Approach to Content Based Image Retrieval System. International Journal of Library Science, 14(3), 41-47. http://ceserpublications. com/index.php/IJLS/article/view/66

Barthes, R. (2009). La cámara lúcida. Paidós.

Carreras Lario, R. (2012). Cómo clasifica Google los resultados de las búsquedas: factores de posicionamiento orgánico. [Tesis doctoral inédita. Universidad Complutense de Madrid].

Codina, L. (2010). MicroStock y Stock Footage: La revolución silenciosa de los Bancos de Imagen. [Presentación en línea] https://es.slideshare.net/Lcodina/microstock-y-stock-footage

Codina, L. (2011). Entender los bancos de imágenes. El profesional de la información, 20(4), 417-423. https://doi.org/10.3145/epi.2011.jul.08

Codina, L., y Lopezosa, C. (2020). Documentación periodística. Búsqueda de imágenes en Internet y bancos de fotografía y vídeo. [Presentación en línea] https://www.lluiscodina.com/bancos-de-fotografia-y-video.

Codina, L., y Palma, M.V. (2001). Bancos de imágenes y sonido y motores de indización en la WWW. Revista Española de Documentación Científica, 24(3), 251-274. https://doi.org/10.3989/redc.2001.v24. i3.58

Cuenca Jaramillo, M.D. (2001). Bancos de imágenes: investigación, conservación y difusión del patrimonio cultural [Tesis doctoral inédita. Universidad Complutense de Madrid].

Defillippi, R., Hunt, P., Dumas, C., y Hung, K. (2014). Crowd-sourcing and the evolution of the microstock photography industry: the case of iStockphoto and Getty Images. En: Defillippi, R. Wikström, P. (Ed.). International perspectives on business innovation and disruption in the creative industries: film, video and photography, (pp. 223-246). Edward Elgar Publishing. https://doi. org/10.4337/9781783475346.00019

Doucet, A.V. (2008). La descripción de las imágenes en internet a través del análisis de 30 bancos de imágenes. Revista general de información y documentación, 18(1), 81-105. https://revistas.ucm.es/ index.php/RGID/article/view/RGID0808110081A 
Figueroa Alfonso, M., Durán Galano, M., Monteagudo Ordaz, M. (1994). Desarrollo y manipulación de bancos de datos con imágenes e información. Revista general de información y documentación, 4(2), 207-212. https://revistas.ucm.es/index.php/RGID/article/view/ RGID9494220207A

Gindin, I.L., y Busso, M.P. (2018). Investigaciones en comunicación en tiempos de big data: sobre metodologías y temporalidades en el abordaje de redes sociales. adComunica, Revista Científica de Estrategias, Tendencias e Innovación en Comunicación, (15), 25-43. http:// hdl.handle.net/10234/173929

Gu, G., Liu, J., Li, Z., Huo, W., y Zhao, Y. (2020). Joint learning based deep supervised hashing for large-scale image retrieval, Neurocomputing, 385, 348-357. https://doi.org/10.1016/j.neucom.2019.12.096

Krauss, R. (2004). Lo fotográfico. Por una teoría de los desplazamientos. Gustavo Gili.

Lin T.Y., Maire, M., Belongie, S., Hays, J., Perona, P., Ramanan, D., Dollar, P., y Zitnick, C.L. (2014). Microsoft COCO: Common Objects in Context. En Fleet, D; Pajdla, T; Schiele, B; Tuytelaars, T. (ed.). Computer Vision -- ECCV 2014, colección "Lecture Notes in Computer Science", vol 8693, (pp. 740-755). Heildeberg (Alemania): Springer. https://doi. org/10.1007/978-3-319-10602-1_48

López Yepes, A. (2002). Los bancos de imágenes en internet. Red digital: Revista de Tecnologías de la Información y Comunicación Educativas, 3. http://reddigital.cnice.mec.es/3/firmas_nuevas/ informes/yepes/1.html

López Yepes, A., y Sánchez Gay, F. (1994). Bancos de imágenes: fototecas en medios de comunicación. Revista general de información y documentación, 4(2), 227-238. https://revistas.ucm.es/index.php/ RGID/article/view/RGID9494220227A

Lucía Mejías, J.M. (2015). El Banco de imágenes del Quijote: 16051915: una herramienta digital para conocer la iconografía quijotesca. Caracteres: estudios culturales y críticos de la esfera digital, 4(1), 8-33. http://revistacaracteres.net/revista/vol4n1mayo2015/ banco-imagenes-quijote/

Maciá Domene, F., y Gosende Grela, J. (2009). Posicionamiento en buscadores. Ediciones Anaya Multimedia.

Marcos Recio, J.C., Sánchez Vigil, J.M., y Olivera Zaldua, M. (2011). Uso en publicidad de fotografías de bancos de imágenes españoles. El profesional de la información, 20(4), 384-391. https://doi. org/10.3145/epi.2011.jul.04

Martínez Comeche, J.A. (2013). La recuperación automatizada de imágenes: retos y soluciones. Revista General de Información y Documentación, 23(2), 423-436. https://doi.org/10.5209/rev_RGID.2013. v23.n2.43137

Ménard, E., y Smithglass, M. (2012). Digital image description: a review of best practices in cultural institutions. Library hi tech, 30(2), 291-309. https://doi.org/10.1108/07378831211239960

Muñoz Castaño, J.E. (2001). Bancos de imágenes: evaluación y análisis de los mecanismos de recuperación de imágenes. El profesional de la información, 10(3), 4-18. http://www.elprofesionaldelainformacion. com/contenidos/2001/marzo/1.pdf

Nielsen, J., y Molich, R. (1990). Heuristic evaluation of user interfaces [Conference]. En CHI '90: Proceedings of the SIGCHI conference on human factors in computing systems (249-256). Press ACM. https:// doi.org/10.1145/97243.97281

Pérez Álvarez, S. (2006). Aproximación al estudio de los sistemas de recuperación de imágenes "CBIR" desde el ámbito de la docu- mentación. Documentación de las Ciencias de la Información, (29), 301-315. https://revistas.ucm.es/index.php/DCIN/article/view/ DCIN0606110301A

Perdices Castillo, L., Perianes Rodríguez, A. (2011). Sistemas de búsqueda y visualización en bancos de imágenes comerciales. El profesional de la información, 20(4), 439-443. https://doi. org/10.3145/epi.2011.jul.11

Perdices Castillo, L., y Perianes Rodríguez, A. (2014). Documentación de fotografías en bancos de imágenes comerciales. El profesional de la información, 23 (5), 534-542. https://doi.org/10.3145/epi.2014. sep.11

Robledano, J. (2002). El tratamiento documental de la fotografía de prensa: sistemas de análisis y recuperación. Editorial Archiviana.

Saorín, T., y Pastor Sánchez, J. A. (2011). Bancos de imágenes para proyectos enciclopédicos: el caso de Wikimedia Commons. El profesional de la información, 20(4), 424-431. https://doi.org/10.3145/ epi.2011.jul.09

Sarwar, A., Mehmood, Z., Saba, T., Qazi, K.A.,Adnan, A., y Jamal, H. (2019). A novel method for content-based image retrieval to improve the effectiveness of the bag-of-words model using a support vector machine. Journal of Information Science, 45(1), 117-135. https://doi. org/10.1177/0165551518782825

Statcounter (2020). Search Engine Market Share Worldwide. https:// gs.statcounter.com/search-engine-market-share

Taute, M. (2013). Stock options. Print, 67(4), 62-65. https://www. printmag.com/in-print/print-august-2013-issue

Tong, L., Tong, R., y Chen, L. (2020). Efficient retrieval algorithm for multimedia image information. Multimed Tools Appl, (79), 9469-9487. https://doi.org/10.1007/s11042-019-07886-6

Trabadela Robles, J. (2017). Imágenes de acceso abierto y los bancos de imagen: estudio de casos. Revista Prisma Social, (18), 309-333. Recuperado de: https://revistaprismasocial.es/article/view/1477

Trabadela Robles, J. (2018). Los bancos de imágenes en internet. Características, funciones y aplicaciones. Icono14.

Villafañe Gallego, J. (2001). Introducción a la teoría de la imagen. Pirámide.

Voronov, V., y Ivanov, V. (2016). The rise of cyber market for stock art: assets aggregation and the wealth of mass creativity. En Soliman, K. S. (Ed.), Innovation management and education excellence vision 2020: from regional development sustainability to global economic growth, (pp. 537-545). International Business Information Management Assoc (IBIMA).

Yin, R.K. (2014). Case study research: design and methods. Sage Publications.

\section{Índice de imágenes}

Fuentes de la muestra de imágenes utilizadas para la búsqueda inversa (recuperadas en octubre de 2018):

- Paisaje A: Blog Ingeniería - https://blogingenieria. com/ingenieria-civil/metodo-eliminar-rascacielos 
- Paisaje B: PicSnaper - http://www.picsnaper. $\mathrm{com} / \mathrm{p} /$ Paisaje-de-Las-montañas-del-bosque.-pirineos-Descargar-Fotos-gratis

- Paisaje C: Radiostip - http://www.radiostip.com. mk/kushta-za-gosti-prez-avgust

- Bodegón A: Cosas De Tenis - https://www.cosasdetenis.com/tipos-de-pelotas-de-tenis

- Bodegón B: Cooperativa.cl. - https://www.cooperativa.cl/noticias/pais/salud/alertas-sanitarias/ los-efectos-de-la-bacteria-hallada-en-dos-productos-lacteos/2017-06-02/204644.html

- Bodegón C: Enrique Dans - https://www.enriquedans.com/2011/08/las-llaves.html

- Retrato A: MisAnimales - https://misanimales. com/los-perros-entienden-cuando-una-persona-esta-mintiendo

- Retrato B: Medium - https://medium.com/@GiraldoJC/los-podcast-y-la-ornitología-37f3132d375d

- Retrato C: WAKYMA - https://wakyma.com/blog/ alimentacion-de-las-tortugas-de-agua

Hay que aclarar que en ninguna web se indicaba el autor de las imágenes (por eso no se especifican aquí), siendo posible además que hayan sido tomadas de otras webs previas.

\section{CV}

Javier Trabadela-Robles. Es licenciado (Ciencias de la Información -Comunicación Audiovisual) y Doctor por la Universidad Complutense de Madrid. Profesor contratado doctor en el Departamento de Información y Comunicación de la Universidad de Extremadura (UEX). Secretario Académico de la Facultad de Ciencias de la Documentación y Comunicación de la UEX. Docente en los grados de Comunicación Audiovisual, Periodismo y de Información y Comunicación (semipresencial) y en el Máster en Gestión de la Información en Redes Sociales y de los Productos Digitales en Internet (virtual).

Miembro de la Asociación Científica de Investigación sobre Tecnologías de la Información y la Comunicación 'Icono14' y del grupo de investigación `AR-CO’ (Área de Comunicación). Coordina las actividades del Aula de Fotografía de la UEX en Badajoz.

Samanta Flores-Jaramillo. Es Técnica superior en imagen. Graduada en Información y Documentación, graduada en Comunicación Audiovisual y Máster Universitario en Investigación en Ciencias Sociales y Jurídicas (Especialidad en Documentación y Comunicación) por la Universidad de Extremadura (UEX).

Trabaja como Técnica Media en Información y Documentación en el Centro de Estudios Extremeños, Diputación de Badajoz.

\section{ocm Observatorio de Cibermedios}

\section{https://observatoriocibermedios.upf.edu/}

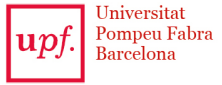

El Observatorio de Cibermedios es una producción del Grupo de Investigación en Documentación Digital y Comunicación Interactiva (DigiDoc) del Departamento de Comunicación de la Universitat Pompeu Fabra.

El Observatorio de Cibermedios (OCM) forma parte del proyecto del Plan Nacional "Narración interactiva y visibilidad digital en el documental interactivo y el periodismo estructurado". RTI2018-095714-B-C21 (MINECO/FEDER), Ministerio de Ciencia, Innovación y Universidades (España). 